\title{
How to compose a narrative: Students approaches and pedagogical implications
}

Anja Thorsten

The self-archived postprint version of this journal article is available at Linköping University Institutional Repository (DiVA):

http://urn.kb.se/resolve?urn=urn:nbn:se:liu:diva-159017

N.B.: When citing this work, cite the original publication.

Thorsten, A., (2019), How to compose a narrative: Students approaches and pedagogical implications, Writing \& Pedagogy, 11(1), 23-47. https://doi.org/10.1558/wap.33676

Original publication available at:

https://doi.org/10.1558/wap.33676

Copyright: Equinox Publishing

http://www.equinoxpub.com/equinox/ 


\section{How to compose a narrative}

- Students' approaches and pedagogical implications

\section{Introduction}

What does it take to write a fictional narrative ${ }^{1}$ with a well-developed plot - and what is a welldeveloped plot? These are some questions that teachers need to consider when teaching how to write narratives. In order to answer them, it is necessary to have knowledge about both narratology and the students' present ability (based on Pang \& Ki, 2016). This combined knowledge can provide insight regarding what aspects of writing the students need to discern in order to develop it even further. For teachers, it is crucial to know which aspects they should make discernible in instruction; otherwise, they will not be able to create tasks and material that are suitable for teaching the ability (Marton, 2015). The present study focuses on nine- to tenyear-olds' ability to write narratives with a well-developed plot. This will be investigated through an inductive analysis of students' written narratives, focusing on different approaches to writing and how various aspects are handled. I will start by giving a brief introduction to narratology theories and provide a framework of what a narrative is. This will be followed by theories and research considering children's writing and their ability in creating narratives.

The fictional narrative has been defined in various ways by different researchers (Stein, 1982). Basically, it consists of an introduction, a plot, and an ending (Chatman, 1978; Genette, 1972/ 1980; Propp, 1928/2015). According to Stein and Glenn (1979), a narrative includes descriptions of the setting and one or more episodes. The episodes consist of initial events, to which the protagonist will respond, which in turn leads to some kind of outcome. These episodes can be more or less elaborated and can relate to each other in various ways. When a narrative is analyzed, it can be separated into story and discourse (Genette,1972/1980). In everyday speech, the term story is used synonymously with narrative. However, when used in narratology, story refers only to the content of a narrative (Chatman, 1978; Genette, 1972/1980). How the story is communicated to the recipient - how it is told and presented - is called discourse.

The content of a narrative, the story, consists of events and character/s (Chatman, 1978; Propp, 1928/2015). A character does something that leads to a change of state (Chatman, 1978). Propp (1928/2015), studying the content of Russian fairy tales, found that all of the approximately 100 tales he studied had the same basic functions ${ }^{2}$ in their structure, even if all were not used in each story. In contrast to this, Chatman (1978) claims that it is difficult to find functions that are representative of all narratives. He argues that the basic part of a narrative is a narrative block, consisting of an obstacle and its resolution, and that most narratives are constructed of several narrative blocks. The main event in a narrative block consists of kernels, necessary for the global logic of the story. Causes and effects primarily connect these kernels. Attached to them, minor events can be told, described by Chatman (1978) as satellites. The function of these is to provide details and enrich the story. The entire story usually ends with some kind of resolution. A modern narrative, however, can also end in other ways, such as the revealing of a state (Chatman, 1978).

\footnotetext{
${ }^{1}$ In this article the term "narrative" refers to the writing of a fictional narrative with a plot.

2 Propp (1928/2015) found 31 different functions. Functions are described as actions that develop the plot, for example An interdiction is addressed to the hero (p. 25) and The hero leaves home (p. 36).
} 
The same story can be told in numerous ways, and the writer makes choices about what to tell and how to tell it; this refers to the concept of discourse (Chatman, 1978, Genette, 1980). According to Iser (1972/1974), the telling of the story is related to what kind of reader the narrator is addressing. This so-called implied reader is not a concrete reader but rather an abstract construct of a potential reader. The chronology of a narrative can differ from that of the story (Chatman, 1978; Genette, 1972/1980). In more advanced narratives, a change of order is usual. It can range from shorter retrospectives or prolepsis (predictions), to longer sequences from different periods in the story's timeline. Another part that will distinguish the narrative from the story is the rhythm. When the narrative is told, its rhythm will never fully be the same as the rhythm of the story. Genette (1972/1980) uses the term duration to describe how much space different events from the story are given, with some scenes described in detail while others are not described at all.

Genette (1972/1980) and Chatman (1978) describe narratives of professional authors, who master several details and aspects of this genre. When children learn how to write narratives they need to learn how to master some of these aspects, but also other ones that are related not only to the writing of narratives but to all kinds of writing.

\section{Children's narrative writing}

Writing a narrative includes abilities in writing as well as knowledge about narrative grammar. Even beginner writers can write the embryo of a story, especially if they have a recipient to address (Evensen, 2006). However, they need to put effort into encoding, leaving less energy for other aspects of the writing. Thus, the ability to handle the technical parts of the writing tend to limit the content, language and length of the written product (Berninger \& Amtmann, 2003; von Koss Torkildsen, Morken, Helland \& Helland, 2015). Most nine- to ten-year-old students have passed the first phase of writing, even if some still struggle with encoding. The major challenge at these ages, according to Christie and Derewianka (2008), is to develop genrespecific writing competences.

To write a narrative is a complex process, in which the ability to plan and organize the writing is central. According to Scardamalia and Bereiter (1987), there are mainly two different approaches in the writing process: a knowledge-telling strategy and a knowledge-transforming strategy. Children who use the knowledge-telling strategy primarily focus on basic genrespecific features and the topic they are writing about, and do not monitor or plan their writing. Younger students mostly use this strategy. They see the content or topic they are writing about as the plan (Scardamalia \& Berieter, 1987; Dunn \& Finley; 2010; McCutchen, 2006). Thus, in their texts, clauses may not be connected to each other or to the global topic (Sanders and Schilperoord, 2006). Since younger children seldom spontaneously reflect on structure and language, they need explicit teaching to focus on these areas (Riley and Reedy (2005). The knowledge-transforming strategy is more advanced (Scardamalia \& Bereiter, (1987). In this case the content, as well as the language and structure, is planned and adjusted to the genre. The students can see their writing at a meta-level. Hence, the writer continuously solves problems concerning how to adjust the content to the rhetorical aspect. That writers focus on the rhetorical aspect, i.e. a potential reader, has been pointed out as central by other researchers as well (Alamargot \& Fayol, 2009; Durán, 2017; Riley and Reedy, 2005; Sanders and Schilperoord, 2006; Thorsten, 2014). Riley and Reedy (2005) assert that it is a challenge for younger children to conceptualize what a hypothetical reader might find difficult to understand in their texts. In a study conducted by Thorsten (2014), ten-year-old students were interviewed about their own written narratives and how they had made them up. The analysis showed that 
students perceive the writing of narratives in different ways. Some saw the narrative as an ongoing fantasy: they did not have a recipient in mind when they wrote - rather, their narratives seemed to be a small part of a larger fantasy. Other statements focused on making it as good as possible for the characters in their own narrative. This led to a focus on creating pleasant events for their own characters, rather than on creating an exciting narrative for possible readers. Statements from the last category showed that the narrative could also be seen as creating an experience for a reader. They talked about how they could write in order to create excitement and interest for those who might read their text.

How students generate text is often reflected in the structure of their writing product (Hounsell, 1984; Sanders \& Schilperoord, 2006). Mastering the global level of a text, including connecting different parts of the text to each other, has proven to be a challenge for many children. In a study conducted by Fuller (described in Berninger, Fuller, \& Whitaker, 1996), 1,800 texts (narrative and expository) by students in Grades 1-9 were analyzed. The analysis focused on the structure of the texts at a local and a global level, and it was shown that students have different ways of relating local parts of the narrative to the global topic. The researchers divided this into several stages in the writing development. In the first stages there were no connections to the global topic at all, and connections at the local level were based on free association between different clauses. In a later stage, students could connect different parts of the story to the global topic, and also have parts in which the content was deepened. Also in Sanders and Schilperoord's (2006) analysis of texts by students aged 10, 12 and 15 years old, the results show that the connection between the local and the global level of the text is a challenge for many writers (foremost in the younger ages, but also for older students).

The text structure is also affected by how genre-specific features are dealt with (Sander $\&$ Schilperoord, 2006). The discernment of the narrative structure is crucial for the ability to both write and tell narratives. McKeough (1984; 1987), with a cognitive developmental perspective and based on Stein and Glenn's (1979) description of story grammar, has studied children's storytelling. The findings of McKeough $(1984 ; 1987)$ show that when four-year-olds tell a story, it usually consists of a series of events, without a plot. At six years, a plot with a problem and an immediate solution is most common. At eight years the main plot may include a sub-plot, with both plots being quickly solved (ibid). In a later study by McKeough and Genereux (2003), it is shown that ten-year-olds create stories with a coherent plot that includes more complications before it is solved. However, they still have some difficulty connecting different episodes with each other. Most twelve-year-olds can handle two distinct stories (through flashbacks) and connect them into a major plot. Alamargot and Fayol's (2009) research overview is in line with these results. It shows that children younger than five years old present events separate from each other, without a plot. When children are seven to eight years old, their stories usually have the basic narrative structure. At eight to nine years old most children can master the basics of time, place and characters, but it is not until the age of ten that a majority of children can handle temporal and causal relations in their narratives.

At a general level, children seem to follow the same developmental stages, but there are still many individual differences (McKeough, 1987; McKeough \& Genereux, 2003). There are also some studies with slightly different results. Evensen (2006) analyzed writing products from preschool children's spontaneous writing. His results indicate that, already at an early age, children use the main structure of a narrative and certain other genre-specific features. Based on these results it seems as if children first incorporate the narrative structure and then, as they get older, enrich it with increasingly more details. In another study, Nordlund (2016) followed 23 students in Grades 1-3 (7-9 years old) and analyzed their narratives. She found differences in this age group concerning whether or not the story has a clear plot. Some students did not 
use the basic narrative structure; their texts had no plot, instead providing descriptions or statements. The results showed that students' texts varied more in language with increasing age. However, students who did not have a clear plot in Grade 1 still lacked it in Grade 3, even if they had developed other parts of their writing. Nordlund (2016) asserts that a reason for this might be that instruction too seldom addresses how to write a well-developed plot. In an intervention study by Thorsten (2014), instructions were designed to support students aged nine to ten years in writing narratives with a well-developed plot. The results showed that students wrote narratives with a more developed plot when they discerned that a story consists of a main problem and solution that can be divided into several problems and solutions. Other studies have also shown that precise instruction is a powerful tool for enhancing students' ability to write narratives (Dunn \& Finley, 2010; Graham, 2006; Saddler \& Asaro, 2007). In an intervention study, Jarvey, McKeough and Pyryt (2008) showed that when the teaching is directed at the students' next developmental level, it is possible to enhance their storytelling ability.

\section{Purpose of the study}

Previous research shows that students master the writing of narratives to different degrees and in various ways (Alamargot \& Fayol, 2009; Berninger et al., 1996; McKeough \& Genereux, 2003; Nordlund, 2016; Sanders \& Schilperoord, 2006). Students' perceptions of and approaches to narrative writing probably affect the way they write (see Hounsell, 1984). Thus, the purpose of this study is to provide knowledge about students' approaches to writing. Furthermore, it is essential to know more about which aspects of writing students might discern, and which aspects they still need to discern in order to further develop their writing. Hence, the following two research questions will be addressed in this paper:

(1) How do nine- to ten-year-old students approach the writing of narratives?

(2) What aspects are critical to discern for nine- to ten-year-old students when writing a narrative?

\section{Variation Theory}

Variation Theory provides a theoretical framework for exploring the research questions. It is a pedagogical theory about the relationship between teaching and learning (Marton, 2015). A basic assumption in this theory is that some aspects are critical for students to discern when learning to master a skill (Lo, 2012; Marton, 2015). According to Pang and Ki (2016), a comparison between qualitatively different ways of perceiving a specific phenomenon will provide insight regarding which aspects are critical to discern. In this phenomenographic analysis the researcher enters a second-order perspective, which means trying to see the assignment from the student's perspective (Marton 1981; Marton \& Booth, 1997). Then it is necessary to "be sensible according to the student's perceived logic" (Pang \& Ki, 2016, p. 11). Approaches, as used in this paper, describe the ways in which students deal with tasks based on their perceptions.

A theoretical assumption, based on Variation Theory, is that students' perceptions of and approaches to narrative writing will influence the way they write (see Marton, 2015; Pang \& Ki, 2016). Hounsell (1984), interviewing students about their writing of a history essay, found out that they perceived and approached the writing in a number of qualitatively different ways. In the analysis of students' written essays, he saw that their perceptions of the writing process were reflected in their final writing products. 


\section{Method}

Data were collected during a larger intervention study (see Thorsten, 2014), which focused on the teaching and learning of the writing of narratives among nine- to ten-year-old students. The intervention was conducted using Learning study ${ }^{3}$ as a method. In this research design, a teacher research group investigates the teaching and learning of an object of learning by analyzing students' learning and then designs, conducts, analyzes and revises lessons in an iterative process. I was a teacher researcher, and led the research group. In this research process, theoretical as well as practice-based knowledge is considered a resource (Thorsten, 2015; $2017)^{4}$. The students wrote narratives (as a pre- and posttest) before and after the intervention. In the present study, 80 of the texts written before the intervention have been analyzed: 40 from two classes in Grade 3 (9 years old) and 40 from two classes in Grade 4 (10 years old). Previously, the students had been taught story-writing based on genre pedagogy (primarily inspired by Gibbons, 2002). The students were asked to write a narrative inspired by a picture. All four classes were given the same instructions. On the picture two people were rowing a boat on a river, and some trees were lying in the water a few meters from the boat. Before the writing, I had a short talk with the students about what they saw in the picture. They were then asked to individually "write a narrative". The whole task was performed during the autumn term during an 80-minute lesson. The study was conducted at a municipal Swedish school, and the children had various socioeconomic and cultural backgrounds. 39 girls and 41 boys took part in the study; all the children and their parents signed written consent to participate. They were informed that the study was voluntary and that the data would be used in research. The names in the examples have been changed in order to keep the students anonymous. Data are stored in a locked cabinet.

\section{Analysis}

The analysis had three major phases: a narratology analysis, an analysis of different storywriting approaches, and finally an analysis of critical aspects.

In the narratology analysis the texts were separated into narrative units, inspired by Propp's (1928/ 2015) description of functions. However, whereas Propp's functions describe the content, my analysis instead focused on the function in the narrative structure. In this sense, the analysis was inspired by Chatman's (1978) description of kernels and satellites. The functions were found through inductive analysis, using codes that were ultimately combined and named, for instance, description of the scene, dramatic event or description of activity.

In the second phase, I searched for different approaches to story-writing. I strived to maintain a second-order perspective, by asking what perceptions about composing a narrative might be behind the various ways of constructing a text (inspired by phenomenography in Hounsell, 1984 and Marton \& Booth, 1997). The narratological analysis was the foundation for this. The texts were compared regarding how they were structured, focusing on the functions in the narrative units, how the units were connected and how much space they were given. Based on this, tentative categories were created. In the process of comparing texts, the categories were changed several times and became increasingly more specified. Ultimately, the analysis resulted in five categories, describing qualitatively different approaches to writing. In phenomenography the aim is to describe different possible ways of approaching a task - not at

\footnotetext{
${ }^{3}$ In Thorsten $(2014 ; 2015 ; 2017)$ the method is described in more detail. The general method is also found in Lo (2012).

${ }^{4}$ In Thorsten (2015; 2017), the issue of teachers' practice-based knowledge in research is addressed.
} 
an individual level but at a collective one (Marton, 1981; Marton \& Booth, 1997). Thus, the focus is on the variety rather than how many students have a certain approach. In a couple of texts more than one approach was seen; in these cases, the texts were separated into entities (each including a few narrative units), which were then placed in different categories. Through this, all the text entities fit into one of the categories. To ensure reliability, another researcher read a fourth of the students' texts and we had a critical discussion about the categories, which led to even more refinements. Finally, the relationships between the categories were investigated and an outcome space was created to show how the categories relate to each other in complexity (see Marton, 1981). One category (composing a narrative) was more complex and advanced than the others (see Figure 1).

In the last phase of the analysis the categories were compared with each other, focusing on differences concerning which aspects of narrative writing were seen in them (based on Pang $\& \mathrm{Ki}, 2016)$. These qualitative differences between the categories were first expressed as initial codes. Then, the codes were compared to each other. Similar codes were connected and named as a critical aspect (i.e. discernment of narrative structure). Various ways of discerning each aspect were also searched for, both between the categories and partially within them (i.e. an expanded narrative structure).

\section{Approaches to writing of narratives}

The results describe different approaches to narrative writing, which will be presented in five qualitatively different categories. The categories describe variation concerning what narrative writing is perceived as. The outcome space is partly hierarchical and partly horizontal. The qualitatively most advanced category is composing a narrative, which is hierarchically more advanced and complex in relation to the other categories. It includes features and elements of the other categories, and is thus placed above them. The four categories describing events, solving a problem, creating action and making jokes are horizontal. They are not more or less complex; rather, these approaches focus on different aspects of narrative writing. First, the four horizontal categories will be presented, followed by a presentation of the most complex category (see figure 1).

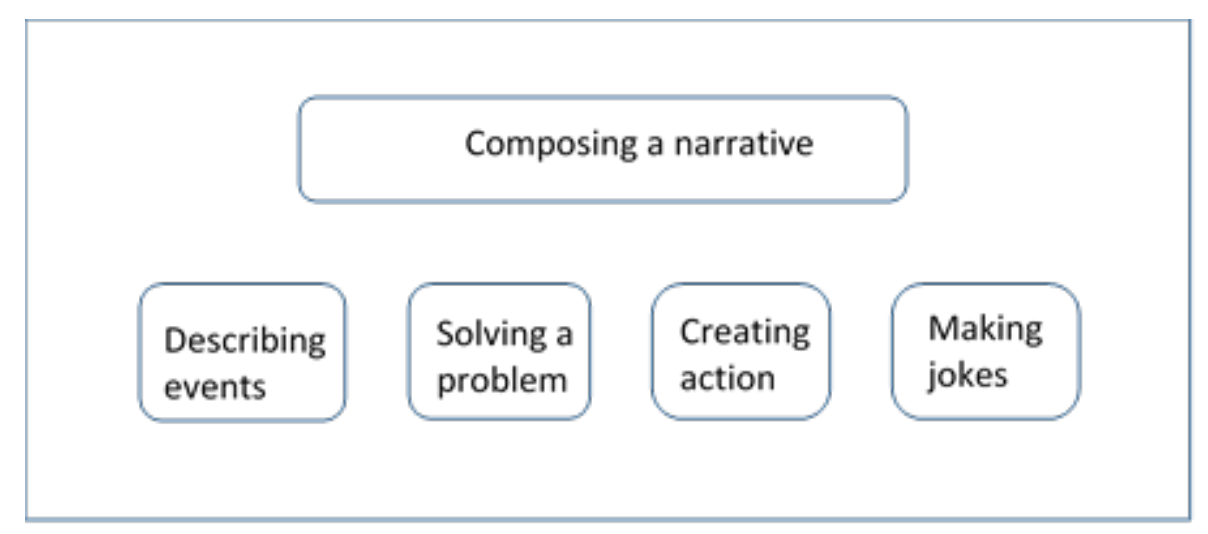

Figure 1: Categories of description: students' approaches to narrative writing.

\section{Describing events}

In texts in this category, narrative writing is approached as describing a series of events. These events focus on some kind of major activity in which the characters partake. They do not 
circulate around a complication or a plot; the focus is rather on descriptions from everyday life and realistic events. This is similar to the recounting genre (see Gibbons, 2002), as the characters in the story are taking part in activities the writer could possibly take part in on some kind of outing or excursion. Even if the text might include some minor problems, these are small issues that a nine- to ten-year-old could encounter on a school trip or in their everyday lives. They are never truly threatening, and are solved very easily. The titles of the texts also indicate that it is the activity and experience that are central for the writer:

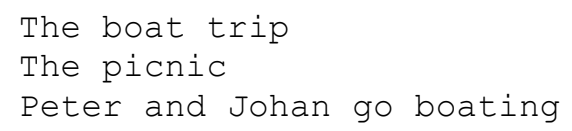

These texts are generally easy to follow, and include descriptions of details from the preparations or other parts of the activity. In the following example, two boys make a small excursion to an island:

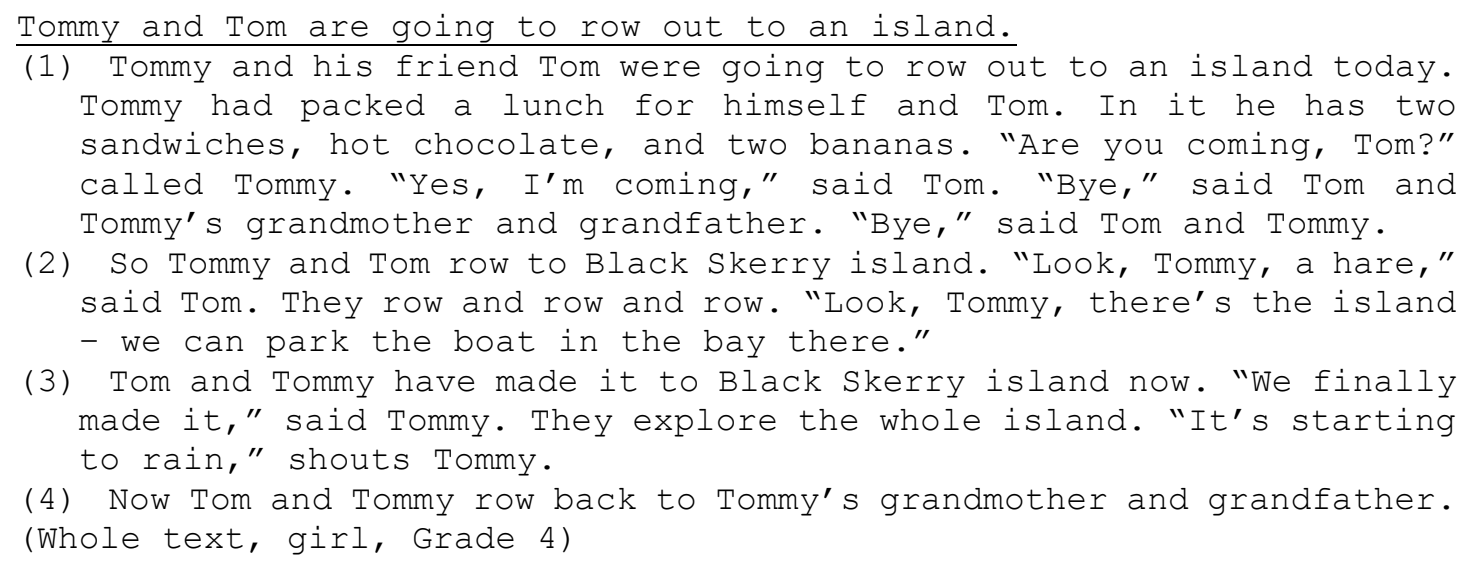

The text is driven by descriptions of activities related to the excursion the children are making. In Unit 1 they are preparing for the trip, and details about the packed lunch are given. The dialog is based on what two children might say when they are about to leave. Also in Unit 2, when they are travelling, small details are given (the rabbit) in order to describe their trip. Unit 3 is about the main activity. It ends with a small problem - it starts to rain. This leads to the children, in Unit 4, rowing back home. In this text the writer provides details, such as the rabbit and the packed lunch, possibly to give a rich picture of the activities the characters partake in. This is seen in all the texts placed in this category. For example, another story describes how many fish each of them caught when they went fishing.

In a couple of texts, there is no connection whatsoever between different events. Only one event is described, such as in the following example:

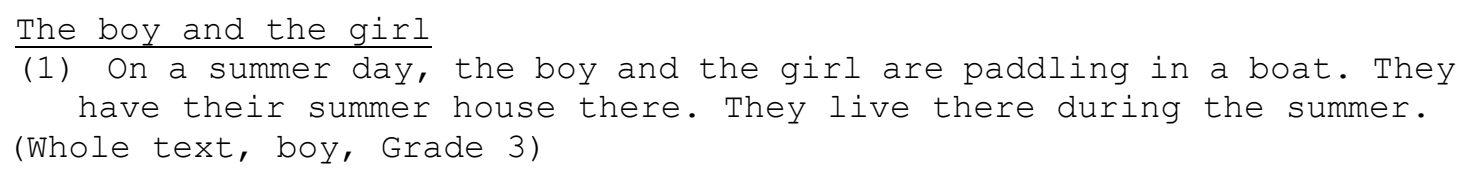

This text consists of only one separate event and a very short description of it. In the first sentence, an activity is described. The next two sentences provide extra information about the characters. It is just as if the boy who wrote this is talking about a photograph, and is giving expanded information about what we can see. 


\section{Solving a problem}

The texts in this category seem to be based on a conception that a narrative should have a problem that is solved as quickly as possible. All the texts in this category revolve around one or (very rarely) a couple of problems. The texts are short and contain very few descriptions. They usually have a brief introduction, and the problem occurs almost immediately. The problems are solved by the characters themselves, by nature, or by a passerby.

Texts in this category contain an introduction, a complication and an ending (as described by Chatman, 1978). Thus, the basic narrative structure is used. However, there are few extra descriptions or actions connected to this structure. Even if all the texts contain a problem that is quickly solved, the writers frame the problems in various ways: a real problem, a potential problem, and an avoided problem.

In most of the texts in this category the characters face a real, sometimes difficult, problem, which is quickly solved. In the following example (with no title), two men are rowing a boat when they come to a waterfall. A neighbor rescues them:

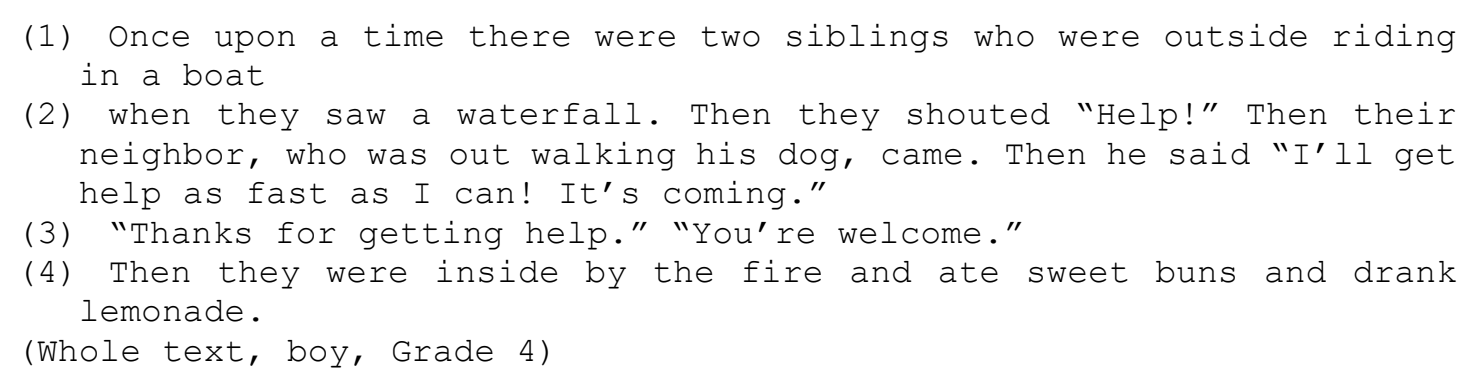

The function in the first part is to give an introduction (1). Very quickly, the problem arises and is solved by a passerby (2). The men thank the helper (3), and the text ends when they are safely home (4).

In other texts in this category, there is more of a potential problem than a real problem. In these texts, the potential danger might turn out not to be a danger. In one text, the characters see a log that disappears and they think they are heading towards a waterfall. It turns out not to be a dangerous waterfall, however, but just a very small one. The text ends, concluding that they can "just keep rowing to where they were headed". All texts with potential problems have a very positive ending:

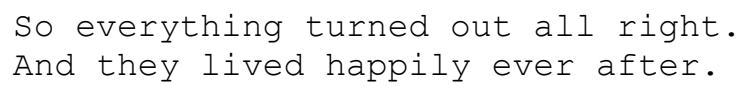

The next example is from a text in which there is a problem, but the problem is avoided. The problem itself is not actually solved, but by avoiding it the characters do not have to face it. This exemplifies the perception that even if a narrative contains some kind of problem, the characters should be able to avoid it. It is possible that the writer identifies with the character, and therefore creates a narrative that is pleasant for him/her (see Thorsten, 2014). This way of handling problems is similar to a potential problem. In these texts, the characters do not have to end up in an uncomfortable situation, as is the case when they are facing and experiencing a real problem:

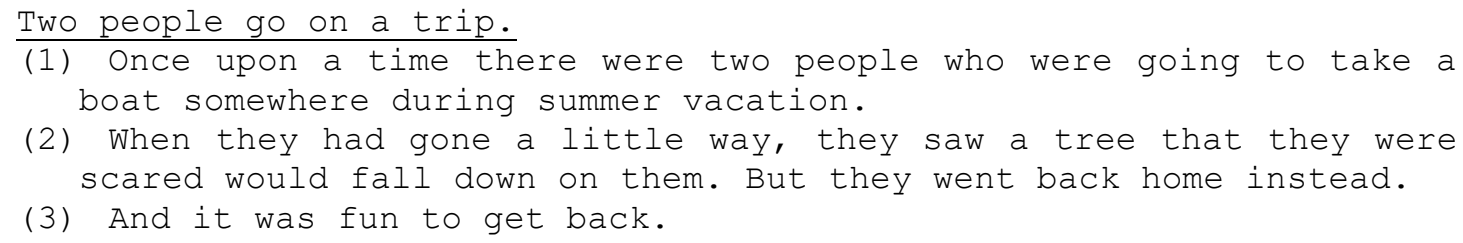


(Whole text, girl, Grade 3)

The whole text evolves around the potential problem, with an introduction (1), followed by a complication with a problem and solution (2), and finally an ending (3). Even if it is only a potential problem, the basic narrative structure can be seen.

Mutual to all the texts in this category is that the whole text circulates around a problem, whether it real or not, and that the problem is solved very quickly.

\section{Creating action}

In this category, the texts are filled with action. Presumably, the writers hold a conception of a narrative as being equal to action. The texts are often short and built on a basic narrative structure, sometimes including several kernels (see Chatman, 1978), with very dramatic events. These dramatic events are loosely connected. There are few descriptions, and new dangers and helpers show up from nowhere:

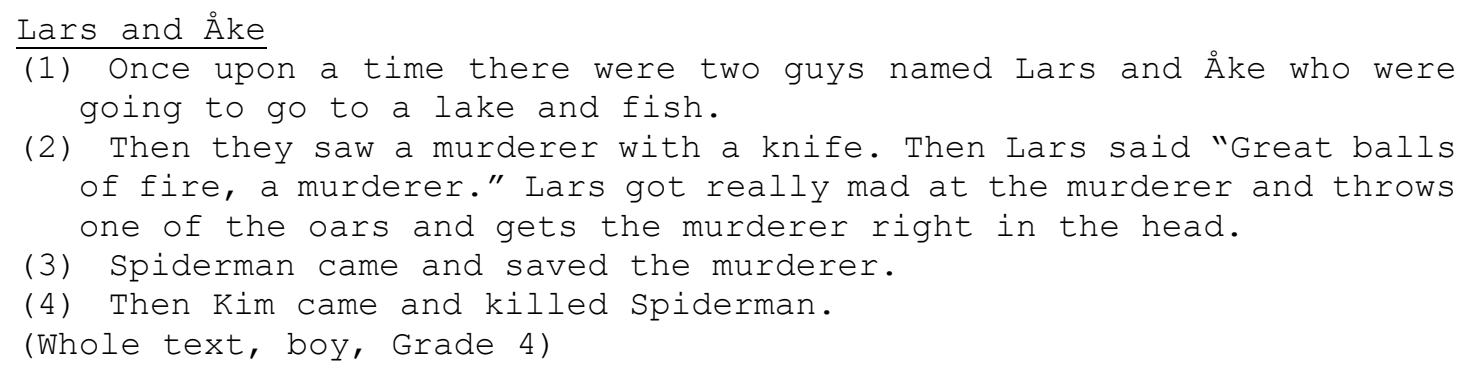

In this text there is an introduction (1), and in the next sentence the first danger arises (2). This leads to a dramatic event whereby Lars throws an oar at the murderer. After this, Spiderman comes from nowhere and the murderer is saved (3). Then, Kim (who is unknown to us) kills Spiderman (4).

This text includes three separate units with dramatic events. The basic structure is possible for a reader to follow and understand, but there are gaps (for example, who Kim is) that make some parts more difficult to follow. In texts in this category, the dramatic events are in the foreground. The descriptions of these events are short and similar to a snapshot, or a quick picture on a screen.

\section{Making jokes}

In this category, the activity of writing a narrative seems to be discerned as a way to communicate with a friend, by making jokes. The material contains two texts written by two boys who were sitting next to each other. During the writing assignment, the boys showed each other what they had written and were laughing at it. It is obvious that they communicated with each other through their texts, naming their characters with their own names and making them do silly things. These things are partly embedded in another story, but the humor is more or less detached from the rest of the narrative. The texts are driven by inside jokes. In this text, Simon writes about himself and his friend Peter:

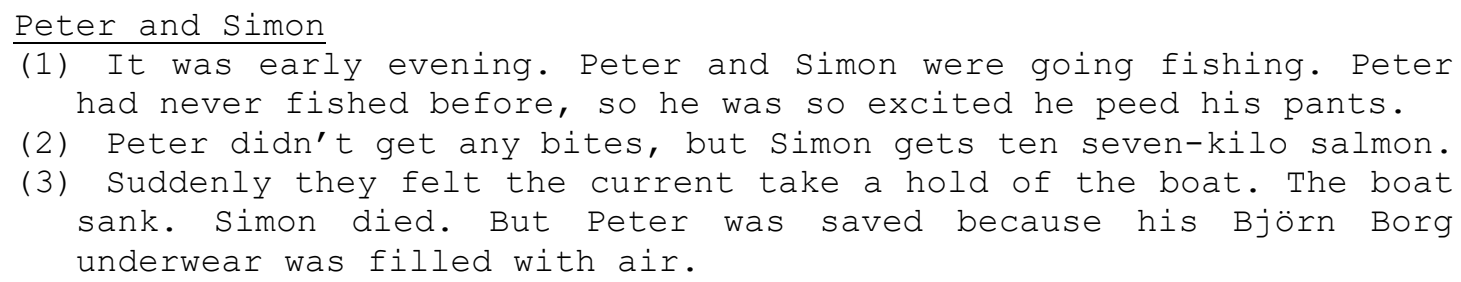


(Whole text, boy, Grade 4)

The first part (1) is a classical introduction, but is combined with the boys' sense of humor. Peter wets himself, which Simon probably finds funny. In the next unit (2) Simon is the one who catches a lot of fish, while Peter gets none. The ongoing joking between the boys drives this. The third section (3) has a plot, whereby the author lets himself get killed, but makes a joke about how Peter is saved. The other boy also wrote a text about himself and his friend, including several jokes about both of them. These texts have the basic characteristics of a narrative (with problem and solution), but also have an extra dimension, which is the joking between the two boys. Since the joking is apparent in many parts of the story, it is probably the major focus for the writers.

\section{Composing a narrative}

In texts in this category, there are clear signs that a reader is being addressed. Various narrative tools are used. This is probably based on a perception of narrative writing as composing a narrative that is exciting and worth reading. This affects both the story and the discourse (see Genette, 1972/1980). All the texts have the classical narrative structure with an introduction, a complication and an ending, but it is expanded. The writer creates and communicates the plot in various ways: creating anticipation, escalating the plot, connecting different plots, and finally connecting the beginning with the end.

Tools are used to create anticipation. This is described as prolepses by Genette (1972/1980), and can increase excitement in a narrative. Already early in the text, there might be some kind of prediction or foreshadowing that there will be a difficulty. In one of the texts, two children are paddling in a river. They then see that the log that is supposed to keep the waterfall's current in order is missing. Describing this is a way to foreshadow that something will happen. Another example is found in the text below. The boys have some difficulties steering the boat, which will turn out to be related to a bigger problem, a waterfall:

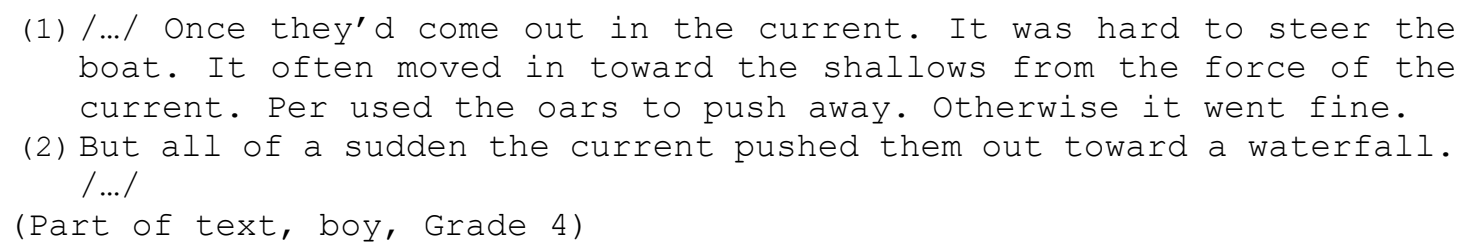

Describing that it is difficult to steer the boat can be seen as a sign to the reader that something is going to happen. The sentence "Otherwise it went fine" signals that the boys still do not understand that they are to face a problem, which they actually discover in the next sentence.

When the writer is escalating the excitement in the plot, the problem the characters face is not solved immediately; they have to struggle a bit before they are safe. This is highly uncommon in the texts, with only a few examples being found in the analysis. In the following example, the solution of one problem leads to a new problem and the plot thickens. Two boys are rowing a boat and approaching a waterfall. Before they fall down the waterfall, they try to paddle back; when this does not work, they try to hold onto a dock:

(1) /.../ They kept going the other way. Until they saw a big waterfall. The boys got scared.

(2) They tried to paddle back, but the rapids were too strong.

(3) But luckily they were able to paddle to the side because the boys had seen a dock that they tried to climb up on. But it wasn't possible to get up on the dock. 
(4) So the boys held on as long as they could. But they weren't strong enough so they went down the waterfall. It was deep.

(5) There was land very close by. So the boys could swim there. /.../

(Part of text, girl, Grade 3)

The plot is built up in several steps: the problem arises - a waterfall (1); a first attempt to solve the problem - rowing back (2); a second attempt - climbing onto a dock (3); a third attempt holding onto the dock (4); the attempts fail - falling down the waterfall; resolution of the plot - swimming to shore (5). This escalation makes the plot more exciting. There are only a few descriptions, though; more would probably have increased the excitement even more.

In some texts, two or more plots are connected, with each plot creating different units of the narrative. These units are not separated, as in the creating action category. Instead, they are tightly connected by a logical and causal chain of events, which is typical of a classical narrative, according to Chatman (1978). Each unit might also include tools for anticipating and escalating the plot. In the following text, a boy is pondering about why he was adopted. While doing this, he can see a man in a boat from his bedroom window. He joins the man in the boat. They end up in a waterfall but rescue themselves using a log, and the boy runs back home. Finally, the boy regrets leaving home, cries, and talks to his adoptive mother:

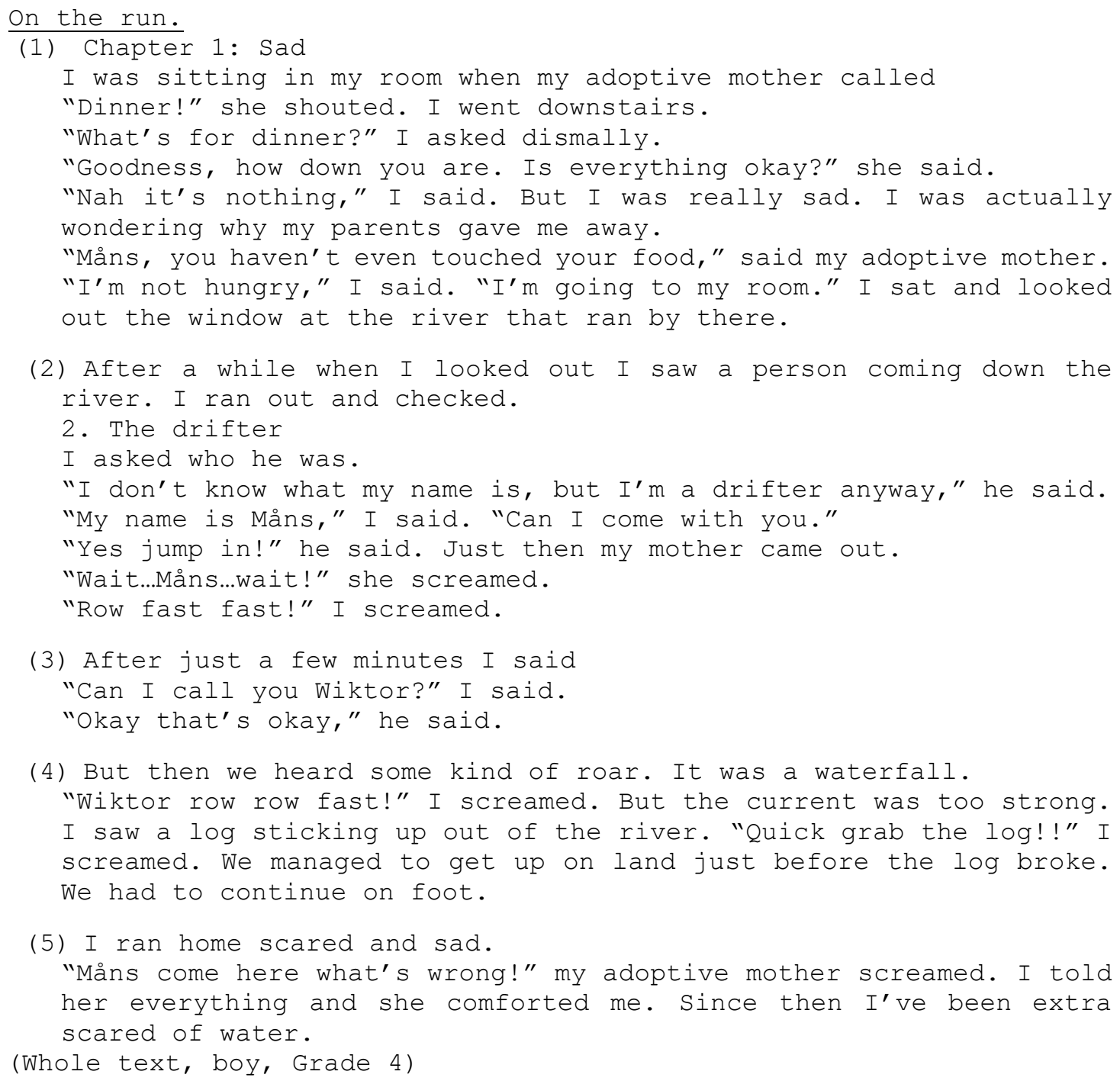

In this text, there are many steps concerning inner as well as outer life. In Unit 1 tension is built, since the boy is so unsatisfied; this in itself is a problem, and anticipates that there might be 
more problems related to it. Unit 2 has to be seen in relation to Unit 1 . When the boy, who is described as sad, sees the boat, he joins the drifter. This thickens the plot and is a solution to the problem described in Unit 1. Unit 3 is a short passage in which the boy and the drifter communicate, and slows the plot down a bit. In Unit 4 a new, big problem arises - a waterfall. They solve the problem quite easily (just like in the solving a problem category), but in the whole text this problem has a larger function. In the last unit (5), the boy comes home and tells his mother "everything". In this way, the start of the narrative is fulfilled at its end. The major plot, that he is unsatisfied, is solved by his having a new experience that will make him talk to his mother about his thoughts. In this example, two plots are connected and the writer connects the beginning and the end.

Texts using different tools (like those presented) are possibly created based on a conception of a narrative as creating an experience for a reader. Even though only a few narrative tools are used, it is possible to see an active writer communicating a story to a reader.

\section{Critical aspects for writing a narrative}

Critical aspects describe what students need to discern in order to master an ability (Marton, 2015; Pang \& Ki, 2016). In this study, five aspects have been found concerning the ability to write a narrative with a well-developed plot. They are based on an analysis of differences in aspects discerned in the categories presented above. The aspects are discerned in various ways and to various degrees, which will be described under each aspect.

\section{Discernment of a reader}

One difference between the categories concerns the discernment of a reader. That this is central has been shown in other research as well (i.e. Scardamalia \& Bereiter, 1987). It affects the writing in several ways, especially through the use of narrative tools, but also concerning how well-developed the plot is. In this study, the degree of awareness of a reader occurs in three different ways: addressing no reader; addressing a specific reader; and addressing various, possible readers. In the creating action category there are no clear signs of addressing a reader. In the making jokes category, however, a clear recipient of the text is apparent. The writer addresses a reader, but not any reader; it is a specific friend. According to Durán (2017), it is helpful for younger students to have a particular reader in mind when writing, and this can raise their audience awareness. A reader is addressed in the composing a narrative category as well, but in this case the reader is not defined - it entails some possible, but unknown, reader/s. Various narrative tools are used to do this. This unknown, possible reader is similar to what Iser (1972/1974) describes as the implied reader. The implied reader is not a concrete, living person, but rather someone who is addressed but still undefined. For a child this might be a challenge, since it means a step between the concrete picture of a reader into a more abstract conception of many possible readers.

\section{Discernment of the function of a narrative}

The function of the narrative genre is most often to entertain and to create an imaginative experience for a possible reader (Bruner, 2002; Gibbons, 2002). However, students discern this function in other ways as well. The following ways have been found in the analysis: to describe, to be in a fantasy, and to entertain a reader. In the describing events category, the focus is on descriptions and describing events and activities. It seems as if a reader is discerned, but the purpose of the narrative is discerned as giving a rich description of events and activities. In 
contrast to this, in texts in the creating action category, the writer seems to be partaking in a fantasy. There is a lack of clues to the reader, and the content is very dramatic. Possibly, the writer is inside the fantasy and enters the story as one does when taking part in roleplay, similar to the ongoing fantasy, described in Thorsten (2014). This can be related to a case study conducted by Lenters (2016), who describes how virtual play in online games can create a rich fantasy world that affects the writing of narratives. In Martre (2013), an analysis of a boy's writing development showed that the boy sometimes simply wanted to fantasize, and thus wrote more for himself than for others. These results imply that the same child can shift between different approaches.

In both the making jokes and composing a narrative categories, the purpose of entertaining someone else can be clearly discerned. The narrative genre can include comedy as well as tragedy, and everyday drama as well as fantasy (Chatman, 1978; Genette 1972/1980), which is seen in these categories.

\section{Discernment of narrative structure}

The discernment of the narrative structure concerns the way in which students handle the plot in a narrative. The narrative structure is handled in the following ways in the categories: no narrative structure; a basic narrative structure; and an expanded narrative structure. Texts in the describing events category lack the narrative structure - they do not circle around some kind of plot. Nordlund (2016) showed similar results, whereby some students seem to write what they call a narrative, but which has no plot. In the other categories in the present study there is a clear plot, with some kind of complication. Most common is the basic narrative structure with an introduction, a problem, and a quick solution (in the solving a problem, creating action and making jokes categories). This structure is typical of the storytelling of sixto eight-year-olds, according to McKeough (1984; 1987). The composing a narrative category not only has a basic narrative structure; the plot is also expanded, which is in line with how tenand twelve-year-olds most often create a narrative (McKeough \& Genereux, 2003).

Evensen (2006) showed that, already in preschool, children can follow some genrespecific features and structures, and that the next step is to develop and enrich this structure. This is also seen in the present study. Most of the texts have the main narrative structure, but it needs to be expanded and enriched.

\section{Discernment of coherence}

This aspect concerns how students handle coherence in their texts. There is a wide range in this aspect. It is seen in three different ways: gaps in the chain of events; connections at the local level; and connection between the local level and the global topic. Gaps in the chain of events are seen especially in the creating action category. Actions and events are loosely connected, and there are gaps that can make the narrative difficult to follow. There are some gaps of this kind in other categories as well, but not as much. The making jokes category is partially coherent. Since the focus in this category is to create humor, some parts are incoherent in relation to the main plot. In this case, the local level is not connected to a global topic. Most of the texts in the solving a problem category are coherent, but sometimes some information is missing. They are primarily connected at the local level, and sometimes also at the global level. This is in line with the results in Berninger et al. (1996), which showed that students have many different ways of dealing with structure at the local and global levels. At some stages, it is common to connect clauses by association, rather than to the global topic (Berninger et al., 1996). Foremost in the describing events and composing a narrative categories, there are 
several examples of a connection between the local and the global level. Even if the text as a whole connects different parts, there are cases in which there are also poor connections between some parts of the text. Sanders and Schilperoord (2006) assert that this is a challenge even for students older than nine to ten years. Thus, this is an area that is continuously developing and that takes a great deal of practice before students can fully master it.

\section{Discernment of duration}

Genette's (1972/1980) description of duration will be used to describe this aspect. What is told and what is not told in a narrative relates partly, but not solely, to coherence. The students handle this in the following ways: basic descriptions, random details, and details relevant to the plot. Most common in the whole sample are basic descriptions and random details. The basic descriptions are primarily seen in the solving problems category. These texts consist of the basic structure of a narrative, with few or no extra descriptions. Details given in this category are often random, in the sense that they do not serve a clear function in the narrative as a whole, which is also seen in the describing events category. The composing a narrative category contains examples of parts that are described more deeply being connected to the plot and serving a function in the global structure of the narrative.

When the students only give basic descriptions, which can be compared to Chatman's (1978) description of kernels, the most important events are told. The satellites, as described by Chatman, have a function of "filling in, elaborating, completing the kernel" (p. 54). This is still a challenge for most nine- to ten-year-old students, even though attempts to master this are seen. In some cases the satellites do not exist at all, while in others they are not logically connected to the plot.

\section{Summary of the critical aspects}

The various ways the critical aspects are discerned in are more or less powerful for the students. In the following table, each aspect is connected to the most powerful way to discern storywriting, based on the analysis of the 80 texts.

Table 1. Summary of critical aspects.

\begin{tabular}{|l|l|l|l|l|l|}
\hline Aspects & $\begin{array}{l}\text { Discernment of } \\
\text { a reader }\end{array}$ & $\begin{array}{l}\text { Discernment } \\
\text { of the } \\
\text { function }\end{array}$ & $\begin{array}{l}\text { Discernment of } \\
\text { the narrative } \\
\text { structure }\end{array}$ & $\begin{array}{l}\text { Discernment } \\
\text { of coherence }\end{array}$ & $\begin{array}{l}\text { Discernment } \\
\text { of duration }\end{array}$ \\
\hline $\begin{array}{l}\text { Most } \\
\text { powerful } \\
\text { way of } \\
\text { discerning }\end{array}$ & $\begin{array}{l}\text { Addressing } \\
\text { various, } \\
\text { possible } \\
\text { readers }\end{array}$ & To entertain & $\begin{array}{l}\text { An expanded } \\
\text { narrative } \\
\text { structure }\end{array}$ & $\begin{array}{l}\text { Connection } \\
\text { between the } \\
\text { local level and } \\
\text { the global } \\
\text { topic }\end{array}$ & $\begin{array}{l}\text { Details } \\
\text { relevant to the } \\
\text { plot }\end{array}$ \\
\hline
\end{tabular}

\section{Discussion}

This study has shown various ways of approaching narrative writing and critical aspects related to it. A basic assumption in Variation Theory is that the aspects we discern affect the way we perceive something, and that this will affect the way we approach it. Based on this assumption, the discernment of critical aspects is central for how students write a story. However, this does not imply that this is the only factor to consider regarding students' writing outcomes. Certainly, children's developmental level will also affect what it is possible for them to achieve, as described by McKeough (1984) and McKeough and Genereux (2003). Results in the present 
study partly correspond with these results. But whereas these studies describe how most children master the ability at different ages, the present study focuses on various ways of doing it at the same age level. Another factor that will influence the writing is the context and the writing prompt. If the students had been given other instructions, it is possible that partly different approaches and critical aspects could have been seen. Even so, the point is that the approaches and critical aspects are not only connected to the individual student or to the context (see Marton \& Runesson, 2015). They are a theoretical description at a collective level, which is connected to story-writing ability in general. It is not a full description; it could be supplemented as well as specified by other similar studies.

The main contribution of this study is the pedagogical implications. The results can be used by teachers teaching story-writing in primarily two ways. Firstly, it can raise awareness about the possible various ways students might approach the task of writing a story. Secondly, the critical aspects can be used as guidelines when teaching narrative writing. As a teacher, it is necessary to have knowledge about what to focus on in instruction. Some of the aspects, such as discernment of a reader, are also addressed in previous research (i.e Scardamalia \& Berieter, 1987), while other ones, such as discernment of duration, are not described as much in relation to student writing. More research is needed on how students handle the aspects, as well as how to teach based on this. According to Case and McKeough (1989) and Jarvey et al. (2008), it is powerful to teach students while focusing on their next developmental level. However, based on Variation Theory, learning is about discerning new aspects from the world around us, and teaching should make these aspects discernable for students (Marton, 2015). Taking this as the departure, it is of the utmost interest to conduct a thorough analysis of which aspects of narrative writing students have, and have not yet, discerned. Then teaching can address these particular aspects. Teaching is not simply telling students what they need to discern or understand. In instruction, the aspects should be made discernable by activities and exercises that will help students incorporate them. Interventions, using Variation Theory as the theoretical framework, would address this issue from a different point of view than is common in previous research. Results from the present study, along with those of other studies in the area, have the potential to provide a new framework to better understand what it takes to write a fictional narrative with a well-developed plot.

\section{References}

Alamargot, D. \& Fayol, M. (2009). Modelling the Development of Written Composition. In R. Beard, D. Myhill, M. Nystrand \& J. Riley (Eds.), The SAGE Handbook of Writing Development. SAGE publications Ltd. (e-book).

Berninger, V. \& Amtmann, D. (2003). Preventing written expression disabilities through early and continuing assessment and intervention for handwriting and/or spelling problems: Research into practice. In H. Swanson, K. Harris, and S. Graham (Eds.), Handbook of Learning Disabilities (pp. 323-344). New York: The Guilford Press.

Berninger, V. W., Fuller, F., \& Whitaker, D. (1996). A process model of writing development across life span. Educational Psychology Review, 8(3), 193-218.

Bruner, J. (2002). Making Stories: Law, Literature, Life. New York: Farrar, Straus and Giroux.

Case, R. \& McKeough, A. (1989). Schooling and the development of central conceptual structures: An example from the domain of children's narrative. International Journal of Educational Research, 13(8), 835-855. 
Chatman, S. (1978). Story and Discourse. Narrative Structure in Fiction and Film. New York: Cornell University Press.

Christie, F. \& Derewianka, B. (2008). School Discourse. New York: Continuum.

Dunn, M. \& Finley, S. (2010). Children's Struggles with the Writing Process. Exploring Storytelling, Visual Arts, and Keyboarding to Promote Narrative Story Writing. Remedial and Special Education, 18 (1), 33-41.

Durán, L. (2017). Audience and young bilingual writers: Building on Strengths. Journal of Literacy Research, 49(1), 92-114. DOI: 10.1177/1086296X16683420.

Evensen, L. S. (2006). Skriveutvikling. Som stadier, som sprang, som orkestrering? In Matre, S. (Ed.), Utfordring for Skriveopplcering og Skriveforsking Idag, (pp. 14-23). Trondheim: Tapir akademisk forlag.

Gibbons, P. (2002). Scaffolding Language Scaffolding Learning. Portsmouth: Heinemann.

Genette, G. (1972/1980). Narrative Discourse. An Essay in Method. New York: Cornell University Press.

Graham. S. (2006). Strategy Instruction and the Teaching of Writing. In C. MacArthur \& S. Graham (eds.), Handbook of Writing Research (pp. 187-207). New York: The Guilford Press.

Hounsell, D. (1984). Contrasting Conceptions of Essay-writing. In Marton, Hounsell \& Enwistle (Eds.), The Experience of Learning (pp. 106-125), Scottish Academic Press.

Iser, W. (1972/1974). The Implied Reader. Patterns of Communication in Prose Fiction from Bunyan to Beckett. Baltimore, Maryland: Johns Hopkins University Press.

Jarvey, M. McKeough, A. \& Pyryt, M. C. (2008). Teaching Trickster Tales: A Comparison of Instructional Approaches. Research in the Teaching of English. 43(1), 42-73.

Lenters, K. (2016). Riding the Lines and Overwriting in the Margins: Affect and Multimodal Literacy Practices, Journal of Literacy Research, 48 (3), 280-316.

Lo, M. L. (2012). Variation Theory and the Improvement of Teaching and Learning. Gothenburg: University of Gothenburg.

Marton, F. (1981). Phenomenography - Describing conceptions of the world around us. Instructional Science, 10, 177-200.

Marton, F. (2015). Necessary Conditions of Learning. New York: Routledge.

Marton, F. \& Booth, S. (1997). Learning and Awareness. Mahwah, NJ: Publisher: Lawrence Erlbaum Associates.

Marton, F. \& Runesson, U. (2015) The idea and the practice of the Learning study. in K. Wood \& S. Sithamparam (Eds.), Realising Learning: Teachers' Professional Development through Lesson and Learning Study (pp. 103-121), London: Routledge.

Martre, S. (2013). Elevteksten som vegvisar til tillpasse opplaering. In R. Karlsdottir \& Lysø, I.H. (Eds.). Laring, Utvikling, Laeringsmiljø: en Innføring i Pedagogisk Psykologi. (pp. 79102) Oslo: Akademika.

McKeough, A. (1984, April 23-27). Developmental Stages in Children's Narrative Composition. Paper presented at the Annual Meeting of the American Educational Research Association $\left(68^{\text {th }}\right)$. New Orleans, LA. 
McKeough, A. M. (1987, July 12-16). Stages in story Telling: A Neo-Piagetian Analysis. Paper presented at the Biennial Meeting of the Society for the Study of Behavioral Development. Tokyo, Japan.

McKeough, A. \& Genereux, R. (2003). Transformation in Narrative Thought During Adolescence: The Structure and Content of Story Composition. Journal of Educational Psychology. 95(3), 537-552.

McCutchen, D. (2006). Cognitive Factors in the Development of Children's Writing. In C. MacArthur \& S. Graham (Eds.), Handbook of Writing Research (pp. 115-130). New York, NY: The Guilford Press.

Nordlund, A. (2016). Berättarteknik i elevberättelser i tidiga skolår. Forskning om Undervisning och Lärande, 2(4), 46-67.

Pang. M. F. \& Ki, W. W. (2016). Revisiting the Idea of "Critical Aspects", Scandinavian Journal of Educational Research, 60(3), 323-336.

Propp, V. (1928/2015). Morphology of the Folktale. Mansfield centre, CT: Martino Publishing.

Riley, J. \& Reedy, D. (2005). Developing young children's thinking through learning to write argument. Journal of Early Childhood Literacy. 5 (29), 29-50.

Saddler, B. \& Asaro. K. (2007). Increasing Story Quality Through Planning and Revising: Effects on Young Writers with Learning Disabilities. Learning Disability Quarterly, 30(4), 223-234.

Sanders, T., J., M. \& Schilperoord, J. (2006). Text Structure as a Windows of the cognition of writing: How Text Analysis Provides Insights in Writing Products and Writing Processes. In: C. A. MacArthur, S. Graham \& J. Fitzgerald (Eds.). Handbook of Writing Research. (pp. 386-402). New York: The Guilford Press.

Scardamalia, M. \& Bereiter, C. (1987). Knowledge telling and knowledge transforming in written composition. In S. Rosenberg (Ed.), Advances in applied psycholinguistics, Volume 2: Reading, writing, and language learning. Rosenberg (pp. 142-175), New York, NY, US: Cambridge University Press.

Stein, N. L. (1982). The definition of a story. Journal of Pragmatics, 6, 487-507.

Stein, N. L. \& Glenn, C. G. (1979). An Analysis of Story Comprehension in Elementary School children: A Test of a Schema. In R. Freedle (Ed.) Discourse processing: Multidisciplinary perspectives (No. 1.2). Norwood, N.J.: Ablex, Inc.

Thorsten, A. (2014). Perspektiv och problemlösning i berättelseskrivande. Vad elever behöver lära sig och hur det kan synliggöras $i$ undervisningen [Perspectives and problem solving in story writing. What pupils need to learn and how teaching can make it visible.] (Licentiate thesis). Jönköping University.

Thorsten, A. (2015). How teachers' practice knowledge is used and challenged in a Learning Study using Variation Theory as a tool. International Journal of Lesson and Learning Studies. 4 (3), 274-287.

Thorsten, A. (2017). Generating knowledge in a Learning Study - from the perspective of a teacher researcher, Educational Action Research, 25(1), 140-154. 
von Koss Torkildsen, J., Morken. F., Helland W. A., \& Helland, T. (2015). The dynamics of narrative writing in primary grade children: writing process factors predict story quality. Reading and Writing, 29, 529-554. 